tages are spread over the entire community, while the rule of tort immunity places the loss squarely on a single individual. Clearly, charitable corporations should, as do private corporations, bear the cost of their tortious acts, and the rule of tort immunity which leaves an undeserved loss on an unfortunate individual should be abolished.

\title{
SECONDARY BOYCOTT UNDER THE SHERMAN ACT AND NORRIS-LAGUARDIA ACT
}

Local 306 of the Motion Picture Machine Operators' Union ${ }^{x}$ threatened to strike Loew's New York distributing center and, through its national union, to strike Loew's production plant on the west coast, unless Loew's agreed to supply films only to Manhattan theatres unionized by Local 306. Similar demands were to be made on seven other leading distributors, ${ }^{2}$ thus threatening a virtual suspension of the entire film industry, if this agreement were not signed. Loew's sought an injunction and a declaratory judgment outlawing the requested agreement under the Sherman Act. Held, relief granted as requested. Loew's, Inc. v. Basson. ${ }^{3}$

Despite the court's holding to the contrary, it seems clear that there was a labor dispute between the parties under the Norris-LaGuardia Act ${ }^{4}$ and that therefore the injunction should not have issued. The court stated that the demands of the union bore "no reasonable relation to wages, hours, health, safety, working conditions, or the right of collective bargaining," and that they were not directed toward any "normal" or "lawful" labor objective..$^{5}$ But in so reasoning the court obviously relied too much on the fact that the union has no quarrel with the company concerning its own employment standards and neglected the importance to the union of the economic support which the company lends to non-organized or rival-organized theatres by continuing its present contracts. Furthermore, the court, in saying that the objective must be "normal" and "lawful," is reading a qualification into the statute. State courts have sometimes done this with their "little Norris-LaGuardia Acts," but it is far

I An affiliate of the International Alliance of Theatrical and Stage Employees, A.F.L.

2 Columbia Pictures Corp., Paramount Pictures, Inc., R.K.O. Radio Pictures, Inc., Twentieth Century-Fox Film Corp., United Artists Corp., Universal Pictures Co., Inc., and Warner Bros. Pictures, Inc.

${ }^{3} 46$ F. Supp. 66 (N.Y. I942).

${ }_{4}$ "The term 'labor dispute' includes any controversy concerning terms or conditions of employment, or concerning the association or representation of persons in negotiating, fixing, maintaining, changing, or seeking to arrange employment ..." § I3 (c), 47 Stat. 70 (I932), 29 U.S.C.A. $\& \times x_{3}$ (c) ( 1942$)$.

5 Loew's, Inc. v. Basson, 46 F. Supp. 66, 7 I (N.Y. I942).

${ }^{6}$ This tendency has been especially marked in New York. American Guild of Musical Artists, Inc. v. Petrillo, 286 N.Y. 226, 36 N.E. (2d) I23 (I94r); Opera on Tour, Inc. v. Weber, 285 N.Y. 348,34 N.E. (2d) 349 (I94 I), noted in 9 Univ. Chi. L. Rev. r7o (r94I). 
more astonishing in a court which is governed by the broad interpretation given the Act by the Supreme Court. ${ }^{7}$

In the opinion of the court, a number of factors emphasized the "illegality" of the union's objectives. For example, in the declaratory judgment, the court held that the union was seeking to induce Loew's to sign an agreement that would be illegal under the Sherman Act. This characterization of the proposed agreement was made on the authority of United States v. Brims. ${ }^{8}$ Actually, the Brims case should not have influenced the court, for Loew's, a company engaged in a type of business totally different from that of the theatres, could never be accused of seeking the elimination of competition, as were the mill operators in the Brims case.

The court also indicated that the proposed agreement would violate a consent decree which Loew's and other distributors had entered into with the government a year prior to this case.9 Sued under the Sherman Act for combining in restraint of trade, the distributors agreed under the decree to supply films in the future to all comers, with certain narrow exceptions. ${ }^{\mathrm{r}}$ Actually, since the decree was aimed at restraints unlike those threatened here, it is at least questionable whether it would be violated by the agreement proposed in the instant case, but the mere possibility is sufficient to create an anomalous situation. If on appeal the decision is reversed-a result which seems inevitable in light of the strict wording of the Norris-LaGuardia Act-Loew's would find itself in a dilemma. It would face threatened economic ruin on the one hand, and a possible violation of a consent decree and breach of express licensing agreements with the theatres on the other. The situation is analogous to the one in which an employer is caught between two statutes, namely, where he is ordered under the Wagner Act to deal with the "in" union and then, under the Norris-LaGuardia Act is denied an injunction when he is picketed by the "out" union. These cases emphasize the inadequacy of the latter statute to dispose satisfactorily of the conflicting interests of parties involved in labor disputes. While the members of Congress responsible for this legislation may not have anticipated such situa-

7 Milk Wagon Drivers' Union, Local No. 753 v. Lake Valley Farm Products, Inc., 3II U.S. 9r (r940); New Negro Alliance v. Sanitary Grocery Co., 303 U.S. 552 (r938); Lauf v. E. G. Shinner \& Co., 303 U.S. 323 (I938); cf. Senn v. Tile Layers Protective Union, 30 U U.S. 468 (1937). See United States v. Hutcheson, 312 U.S. 219 (I94I).

${ }^{8} 272$ U.S. 549 ( 1926 ). The Brims case involved an agreement among the woodwork mills, local contractors, and the carpenters' union to secure local labor stability and to exclude the competitive entrance into the Chicago market of outside non-union-made wood trim.

9 United States v. Paramount Pictures et al., Civil Action No. 87-273, D.C.N.Y. (I940) (unreported).

Io "No distributor defendant shall refuse to license its pictures for exhibition in an exhibitor's theatre on some run (to be designated by the distributor) upon terms and conditions fixed by the distributor which are not calculated to defeat the purpose of this Section, if the exhibitor can satisfy reasonable minimum standards of theatre operation and is reputable and responsible, unless the granting of a run on any terms to such exhibitor for said theatre will have the effect of reducing the distributor's total film revenue in the competitive area in which such exhibitor's theatre is located." Ibid., at Section VI. 
tions, it seems that amendatory legislation should now be considered. The applicability of the Norris-LaGuardia Act might be restricted in cases where a labor group attempts to induce a violation of the Sherman Act or to interfere with an established bargaining set-up.

If the case is reversed, and Loew's chooses to submit to the threatened strike rather than risk a violation of its consent decree and also a violation of its agreements with the threatres, it can then sue the union for triple damages under the Sherman Act or request the Anti-trust Division to prosecute. Such a case would center around the legality of the secondary boycott, since that is the weapon which the union is threatening to employ. The mere fact that Loew's, rather than the theatres, is complaining, does not in any way imply that the coercion is primary rather than secondary. A strike aimed solely at the employer is a type of primary boycott, a primary boycott being the deliberate refusal by one person or group to deal with another. The boycott becomes secondary when $A$ (in this case, the union), either through a strike or a refusal to patronize, boycotts $B$ (Loew's) in order to force $B$ in turn to boycott $C$ (the theatres). In most secondary boycott cases, $B$ (manufacturer's customer) submits uncomplainingly in order to maintain good relations with $A$, and $C$ (manufacturer) suffers, just as $\mathrm{A}$ intended. ${ }^{\mathrm{II}}$ Hence, most suits against secondary boycotts are brought by $\mathrm{C}$, not $B .^{x 2}$ But this is because $C$ in those cases is the seller who resents loss of custom, whereas $B$, the buyer, finds it easier to patronize someone else than to defy the union. On the other hand, when $B$ is the seller and $C$ the buyer, as in the instant case, B is likely to be less yielding, for he finds it more diffcult to build up a new market as a seller than to switch his patronage as a buyer. In these cases $B$ is the one who sues instead of $\mathrm{C}$. But that is no indication that the boycott is primary rather than secondary.

Once it is decided that certain activity constitutes a secondary boycott, the problem is by no means solved, however. For it remains to be seen when, if ever, this organizational gambit is to be held illegal under the Sherman Act. In Apex Hosiery Co. v. Leader, ${ }^{\mathrm{T} 3} \mathrm{Mr}$. Chief Justice (then Associate Justice) Stone, speaking for the majority, declared that labor activities did not constitute a violation of the Sherman Act, unless they were aimed at the suppression of competition and the control of national markets or in fact did substantially affect such competition. ${ }^{14}$ Union activity which will tie up an entire industry, as in the present case, is obviously substantial in its effect.

But that Mr. Chief Justice Stone is reluctant to use his "substantiality"

Ix This was true in all three of the leading boycott cases. Bedford Cut Stone Co. v. Journeymen Stone Cutters' Ass'n., 274 U.S. 37 (x927); Duplex Printing Press Co. v. Deering, 254 U.S. 443 (I92I); Loewe v. Lawlor, 208 U.S. 274 (Ig08).

I2 This likewise was true in the three leading boycott cases, note II supra.

${ }^{13} 3$ I0 U.S. 469 (1940).

${ }^{14}$ For an analysis of this criterion, see Gregory, Union Peacetime Restraints in Collective Bargaining, to Univ. Chi. L. Rev. 180-82 (I943). 
doctrine ${ }^{15}$ appears in his concurring opinion in United States $v$. Butcheson ${ }^{16}$ for there he ignored the government's contention that there was a secondary consumption boycott similar to that in Loewe v. Lawlor. ${ }^{17}$ Since the request not to buy had come originally from the strikers themselves, he treated it simply as "a publication .... that the employer is unfair to organized labor and requesting the public not to patronize him," and this, he continued, is no more than a form of picketing and "an exercise of free speech."x8 This verbal apology hardly accounts for the actual concerted nationwide response to that request which was charged in the indictment. 19 It would have been far more clarifying had he either admitted the boycott and said that its effect on the market was not "substantial," or simply overruled the boycott precedents once and for all.

If the case ever gets before him as a damage suit or anti-trust prosecution, he again has three choices. He may ignore the secondary boycott, treating the coercion as primary since $B$ as well as $C$ has been made to suffer, and, under the old Duplex construction of the Clayton Act, Section 20,20 avoid the imposition of liability. Or he may, if he favors liability, point out the substantial manner in which the union's activity is affecting the market and put his long-ignored doctrine to work. Or, if he does not favor liability, he may, as a last resort, accept Mr. Justice Frankfurter's unfortunate casuistry, as expressed in the Hutcheson case.

This opinion of Mr. Justice Frankfurter in the Hutcheson case depends upon a curious juxtaposition of three statutes ${ }^{2 x}$ by which he concluded for the majority that no union, if it had confined its activities to those enumerated in Section 20 of the Clayton Act and Section 4 of the Norris-LaGuardia Act, could be said to have violated the Sherman Act, so long as it had acted in its own self-interest and had not combined with any non-labor group. Certainly the threatened union recourse in the present case would pass muster under such a formula. Mr. Justice Frankfurter's emphasis on the means used by laboring groups is sharply opposed to Mr. Chief Justice Stone's exclusive consideration of ends in his Apex opinion. This basic divergence in approach, particularly in view of the history

xs A stimulating discussion of the doctrine is contained in the opinion of Judge Learned Hand in United States v. Gold, II4 F(2d) 236(C.C.A. 2d) (I94O), where the boundary of substantiality was held not to include the interference in question. See Gregory, The Sherman Act v. Labor, 8 Univ. Chi. L. Rev. 222, 236 (194r).

${ }^{26} 3 \times 2$ U.S. 219, 237 (I94I).

${ }^{17} 208$ U.S. 274 (I908).

${ }^{18}$ United States v: Hutcheson, 3I2 U.S. 219, 243 (I94I), citing Thornhill v. Alabama, 3Io U.S. 88 (I940).

19 Record, at Io, United States v. Hutcheson, 312 U.S. 2 Ig $_{9}$ (194r).

${ }^{20} 3^{8}$ Stat. 738 \& 20 (I9I4), 29 U.S.C.A. $\$ 52$ (I942).

${ }_{2 x}$ The Sherman Act, 26 Stat. 209 (I890), 15 U.S.C.A. $\S$ I (194I); the Clayton Act, 38 Stat. 738 (I9I4), 29 U.S.C.A. $\$ 52$ (1942); and the Norris-LaGuardia Anti-Injunction Bill, 47 Stat. 70 (I932), 29 U.S.C.A. § IOI (I942). 
of the Norris-LaGuardia Act and of the conditions prompting its adoption, ${ }^{22}$ lends support to the current view that Mr. Justice Frankfurter's opinion is but an anomalous attempt to whitewash all union undertakings as long as they are conducted in a gentlemanly fashion. ${ }^{23}$ It is, therefore, possible that the Court will ultimately treat this opinion as mere dictum and adopt Mr. Chief Justice Stone's concurring opinion as the proper rationale. ${ }^{24}$ If the Chief Justice could then be prevailed upon to put his "substantiality" test to work, the Court could, without loss of face, decide against the union in the newly-brought case we have been considering. ${ }^{25}$

\section{SECRET LIENS AND THE CHANDLER ACT}

Decisions interpreting the preference provisions of the Bankruptcy Act of I 898 reveal the presence of two conflicting policies; ${ }^{\mathrm{T}}$ Congress and the Supreme Court appear to have chosen opposite sides in the controversy between the general creditors and particular creditors who claim the benefit of secret liens. Behind legal phraseology is concealed a balancing of the important economic interests. Interpretations by the Court of successive amendments to Section $60^{2}$

22 The desire for procedural reform to curb the use of injunctions appears to have been the sole motive behind the statute. Both foes and supporters of the bill agreed that it was not in any way meant to widen civil and criminal immunities. 75 Cong. Rec. 5462 et seq. (1932). Mr. Justice, then Professor, Frankfurter himself asserted then that the Act "explicitly applies only to the authority of United States courts 'to issue any restraining order or injunction.' All other remedies in federal courts and all remedies in state courts remain available." Frankfurter and Greene, The Labor Injunction 220 (1930).

${ }^{23}$ Steffen, Labor Activities in Restraint of Trade: The Hutcheson Case, 36 IIl. L. Rev. I (I94I); Gregory, The New Sherman-Clayton-Norris-LaGuardia Act, 8 Univ. Chi. I. Rev. 503 (I94I); see Landis, The Apex Case-Addendum, 26 Cornell L. Q. 212A (I94I).

24 This is a very real possibility in view of the somewhat analogous manner in which the doctrine of picketing as free speech enunciated in Thornhill v. Alabama, 310 U.S. 88 (I940), has been drastically limited by the case of Carpenter and Joiners Union of America, Local No. $2{ }^{2} 3$ v. Ritter's Cafe, $3 \times 5$ U.S. 722 (I942). But the prompt affirmance of the Hutcheson case in three cases indicates that perhaps the time for overhauling has not yet arrived. United States v. Building and Construction Trades Council of New Orleans, 4 C.C.H. Lab. Cas. $\prod_{51, I I 8}$ (I94I), aff'd $3^{\mathrm{I} 3}$ U.S. 539 (r94I); United States v. United Brotherhood of Carpenters and Joiners of America, 4 C.C.H. Lab. Cas. I5x,II8 (r94r), aff'd $3^{1} 3$ U.S. 539 (I94I); United States v. Carrazzo, 37 F. Supp. Igx (Ill. x94r), aff'd sub nom. Int'I Hod Carriers' and Com-

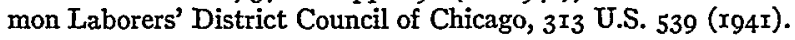

${ }_{25}$ It should be noted that most of the theatres are already organized by a rival union; but this cannot be expected to influence the decision, since a jurisdictional dispute has already been presented to the Court in the Hutcheson case and appeared to disturb none of the judges. See Gregory, Union Peacetime Restraints in Collective Bargaining, Io Univ. Chi. L. Rev, I88 ff. (I943), for proposed legislative solutions to the growing problem of internecine conflict.

I Britton, Equitable Liens-A Tentative Analysis of the Problem, 8 N.C.L. Rev. 388 (x930); Validity of Liens Against a Trustee in Bankruptcy, 34 Yale L.J. 89I (1925); Voidability in Bankruptcy of Transfers Recorded within the Four Months Period, 44 Yale L.J. Iog (r934).

2 Chandler Act $\S 60(a), 52$ Stat. 869 (I938), II U.S.C.A. $\S 96$ (a) (Supp. r942): "A preference is a transfer, as defined in this Act, of any of the property of a debtor to or for 